\title{
A SURVEY OF AVAILABLE MOLECULAR MARKERS FOR VERTEBRATE SPECIES PRESENT IN COMUNIDAD DE MADRID
}

\author{
L. Boto*
}

\begin{abstract}
In this paper I present a survey for molecular markers available for Vertebrate species inhabiting the Comunidad de Madrid, with the aim of being useful to researchers working on the characterization of animal biodiversity in this area.
\end{abstract}

Key words: Molecular markers, Vertebrate, Madrid.

\section{RESUMEN}

Estudio de los marcadores moleculares disponibles para las especies de vertebrados presentes en la Comunidad de Madrid

En este trabajo presento los resultados de una búsqueda en bases de datos de marcadores moleculares para especies de Vertebrados presentes en la Comunidad de Madrid, en la esperanza de que este trabajo pueda ser de utilidad para aquellos investigadores involucrados en la caracterización de biodiversidad animal en esta Comunidad.

Palabras clave: Marcadores moleculares, Vertebrados, Madrid.

\section{Introduction}

Today, molecular markers are a valuable tool for taxonomic and conservation studies allowing serious inferences in phylogeography, genetic structure of populations, conservation status, and so on (Bruford \& Wayne, 1993; Tautz et al., 2003; Avise, 2004).

For this reason, I consider that a survey of available molecular markers for Vertebrate species inhabiting in Comunidad de Madrid in sequence databases could be interesting as a research tool for biodiversity present in this area, giving researchers an overview to molecular knowledge for the species under scrutiny, and contributing to define gaps that can be filled subsequently.
The present survey is realised with this in mind, searching in sequence databases for mitochondrial, nuclear, and microsatellite (frequently repeated, highly polymorphic short sequences) sequences for vertebrate species or genera present in Comunidad de Madrid.

This approach, however, can have relative value only, since new sequences in sequence databases become available almost every day, and could make data shown in this work rapidly obsolete. In this sense, I believe that incorporating these data into a new database in progress in the Museo Nacional de Ciencias Naturales, and their continued review, can increase the value of the work.

* Dpto. Biodiversidad y Biología Evolutiva. Museo Nacional Ciencias Naturales. CSIC. C/ José Gutiérrez Abascal 2. 28006 Madrid. SPAIN. Phone number: (34) 914111328. Fax: (34) 915645078. E-mail: mcnb119@mncn.csic.es 
Table 1.- Sequences in databases for fish present in Comunidad de Madrid.

Tabla 1.- Secuencias en las bases de datos para peces presentes en la Comunidad de Madrid.

\begin{tabular}{|c|c|c|c|c|c|}
\hline Species & Sequences & $\begin{array}{l}\text { Mitochondrial } \\
\text { sequences }\end{array}$ & $\begin{array}{c}\text { Nuclear } \\
\text { sequences }\end{array}$ & Microsatellites & Remarks \\
\hline $\begin{array}{l}\text { Ameiurus melas/ } \\
\text { Ictalurus melas }\end{array}$ & 13 & 12 & 1 & 0 & $\begin{array}{l}85 \text { sequences to the Genus ( } 55753 \\
\text { sequences for Ictalurus) } \\
\text { Many microsatellites }\end{array}$ \\
\hline Barbus bocagei & 28 & 25 & 3 & 0 & $\begin{array}{l}733 \text { sequences to the Genus } \\
22 \text { microsatellites }\end{array}$ \\
\hline Barbus comizo & 14 & 14 & 0 & 0 & idem \\
\hline Carassius auratus & 745 & yes & yes & 21 & 790 sequences to the genus \\
\hline $\begin{array}{l}\text { Chondrostoma arcasii/ } \\
\text { Rutilus arcasii }\end{array}$ & 29 & 29 & 0 & 0 & $\begin{array}{l}185 \text { sequences to the genus ( } 55 \text { for } \\
\text { Rutilus) } \\
5 \text { microsatellites for } \text { R. rutilus }\end{array}$ \\
\hline $\begin{array}{l}\text { Chondrostoma lemmingii/ } \\
\text { Rutilus lemmingii }\end{array}$ & 10 & 10 & 0 & 0 & idem \\
\hline Chondrostoma polylepis & 4 & 4 & 0 & 0 & idem \\
\hline Cobitis calderoni & 12 & 12 & 0 & 0 & 277 sequences to the Genus \\
\hline Cobitis paludica & 59 & 59 & 0 & 0 & idem \\
\hline Cyprinus carpio & 11616 & yes & yes & 13 & $\begin{array}{l}15 \text { microsatelllites for C.auratus } \\
\text { are conserved }\end{array}$ \\
\hline Esox lucius & 108 & 42 & 40 & 26 & 171 sequences to the genus \\
\hline Gambusia holbrooki & 4 & 4 & 0 & 0 & $\begin{array}{l}71 \text { sequences to the Genus } \\
7 \text { microsatllites for G. affinis. } \\
3 \text { described for G. holbrooki are } \\
\text { not in GenBank }\end{array}$ \\
\hline $\begin{array}{l}\text { Gobio lozanoil } \\
\text { Gobio gobio }\end{array}$ & 58 & 44 & 14 & 0 & 67 sequences to the Genus \\
\hline Lepomis gibbosus & 11 & 8 & 3 & 0 & $\begin{array}{l}215 \text { sequences to the genus } \\
9 \text { microsatellites for } L \text {. margi- } \\
\text { natus, } 1 \text { for } L . \text { macrochirus }\end{array}$ \\
\hline Micropterus salmoides & 73 & 47 & 20 & 6 & $\begin{array}{l}269 \text { sequences to the genus. } \\
11 \text { microsatellites for } M \text {. } \\
\text { dolomieu }\end{array}$ \\
\hline Oncorhynchus mykiss & 242135 & yes & yes & 967 & 246644 sequences to the Genus \\
\hline Silurus glanis & 21 & 3 & 2 & 16 & 42 sequences to the Genus \\
\hline Salmo trutta & 870 & yes & yes & 40 & 114040 sequences to the Genus \\
\hline $\begin{array}{l}\text { Squalius alburnoides/ } \\
\text { Tropidophoxinellus albu }\end{array}$ & $\begin{array}{r}67 \\
\text { noides/ }\end{array}$ & 67 & 0 & 0 & $\begin{array}{l}149 \text { sequences to the Genus ( } 2 \\
\text { for Tropidophoxinellus) }\end{array}$ \\
\hline \multicolumn{5}{|c|}{ Rutilus alburnoides } & 6 microsatellites for $S$. aradensis \\
\hline $\begin{array}{l}\text { Squalius pyrenaicus/ } \\
\text { Leuciscus pyrenaicus }\end{array}$ & 47 & 47 & 0 & 0 & $\begin{array}{l}\text { idem. ( } 633 \text { for Leuciscus) } 5 \\
\text { microsatellites for } L . \text { idus and } \\
5 \text { for } R . \text { rutilus that are conser } \\
\text { ved in } L . \text { idus }\end{array}$ \\
\hline Tinca tinca & 38 & 7 & 30 & 1 & \\
\hline
\end{tabular}


Table 2.- Sequences in databases for Amphibia present in Comunidad de Madrid.

Tabla 2.- Secuencias en las bases de datos para anfibios presentes en la Comunidad de Madrid.

\begin{tabular}{|c|c|c|c|c|c|}
\hline Species & Sequences & $\begin{array}{l}\text { Mitochondrial } \\
\text { sequences }\end{array}$ & $\begin{array}{c}\text { Nuclear } \\
\text { sequences }\end{array}$ & Microsatellites & Remarks \\
\hline Alytes cisternasii & 11 & 5 & 0 & 6 & $\begin{array}{l}105 \text { sequences to the Genus } \\
11 \text { microsatellites for } A \text {. muletensis }\end{array}$ \\
\hline Alytes obstetricans & 57 & 51 & 6 & 0 & $\begin{array}{l}\text { idem. } \\
\text { Genome mitochondrial completed }\end{array}$ \\
\hline Bufo bufo & 60 & 34 & 10 & 16 & 1772 sequences to the Genus \\
\hline Bufo calamita & 54 & 35 & 1 & 18 & idem \\
\hline Discoglossus galganoi & 78 & 77 & 1 & 0 & $\begin{array}{l}\text { Genome mitochondrial completed } \\
204 \text { sequences to the Genus }\end{array}$ \\
\hline Discoglossus jeanneae & 72 & 71 & 1 & 0 & idem \\
\hline Euproctus asper & 15 & 13 & 2 & 0 & 22 sequences to the Genus \\
\hline Hyla arborea & 25 & 4 & 4 & 17 & 1147 sequences to the genus \\
\hline Hyla meridionalis & 11 & 3 & 8 & 0 & idem \\
\hline Pelobates cultripes & 22 & 15 & 7 & 0 & 37 sequences to the Genus \\
\hline Pelodytes punctatus & 21 & 17 & 4 & 0 & 30 sequences to the Genus \\
\hline Pleurodeles walt & 134 & 81 & 53 & 0 & 225 sequences to the Genus \\
\hline Rana iberica & 15 & 7 & 8 & 0 & $\begin{array}{l}2022 \text { sequences to the Genus } \\
\text { Microsatellites }\end{array}$ \\
\hline Rana perezi & 12 & 9 & 3 & 0 & idem \\
\hline Salamandra salamandra & 188 & 172 & 5 & 11 & 226 secuences to the Genus \\
\hline Triturus alpestris ${ }^{1}$ & 10 & 2 & 1 & 7 & $\begin{array}{l}427 \text { sequences to the Genus } \\
64 \text { Microsatellites }\end{array}$ \\
\hline Triturus boscai ${ }^{2}$ & 6 & 6 & 0 & 0 & idem \\
\hline Triturus marmoratus & 4 & 3 & 1 & 0 & idem \\
\hline Triturus pygmaeus & 1 & 1 & 0 & 0 & idem \\
\hline
\end{tabular}

(1) Now Mesotriton alpestris. (2) Now Lissotriton boscai.

\section{Methods}

Each species present in Comunidad de Madrid has been searched for number of sequences, using the Taxonomy browser of the WEB page of NCBI (National Center for Biotechnology information USA) (http://www.ncbi.nlm.nih.gov/Taxonomy /taxonomyhome.html). This information has been edited, sorting them into mitochondrial and nuclear sequences and microsatellites when sequence number output is less than 200 sequences. Sequences available for the corresponding genera, with special focus in the presence of microsatellites, have also been analyed.

In cases with a sequence number output greater than 200, I search specifically for the presence of microsatellite using the Entrez option with a query: "Genus name + microsatellite".

In the case of Fish I took the distribution show in the Atlas y Libro Rojo de los Peces continentales de España (Doadrio, 2002) as the basis of the their presence in the region. For Amphibia, I followed Martínez-Solano \& González Fernández (2003). In relation to Reptilia, I used the Atlas y Libro Rojo de los Anfibios y Reptiles de España (Pleguezuelos et al., 2002). In the case of Aves, I split the species present in Madrid into sedentary and migrants on the basis of the Anuario Ornitológico de Madrid 2002 (De la Puente Nilsson et al., 2002), excluding species cited as accidental. For Mammals, I use the Atlas de los mamíferos terrestres de España (Palomo \& Gisbert, 2002). For main synonymies I 
Table 3.- Sequences in databases for Reptilia present in Comunidad de Madrid.

Tabla 3.- Secuencias en las bases de datos para repriles presentes en la Comunidad de Madrid.

\begin{tabular}{|c|c|c|c|c|c|}
\hline Species & Sequences & $\begin{array}{l}\text { Mitochondrial } \\
\text { sequences }\end{array}$ & $\begin{array}{c}\text { Nuclear } \\
\text { sequences }\end{array}$ & Microsatellites & Remarks \\
\hline Acanthodactylus erithrurus & 41 & 41 & 0 & 0 & 87 sequences to the Genus \\
\hline Anguis fragilis & 8 & 3 & 5 & 0 & \\
\hline Blanus cinereus & 3 & 0 & 3 & 0 & 5 sequences to the Genus \\
\hline Coluber hippocrepis ${ }^{1}$ & 3 & 3 & 0 & 0 & 60 sequences to the Genus \\
\hline Coronella austriaca & 29 & 6 & 1 & 22 & 39 sequences to the Genus \\
\hline Coronella girondica & 10 & 9 & 1 & 0 & $\begin{array}{l}22 \text { microsatellites for } \\
\text { C. austriaca }\end{array}$ \\
\hline Chalcides bedriagai & 0 & 0 & 0 & 0 & 139 sequences to the genus \\
\hline $\begin{array}{l}\text { Chalcides striatus/ } \\
\text { Chalcides chalcides }\end{array}$ & 6 & 4 & 2 & 0 & idem \\
\hline Chrysemys scripta & 8 & 0 & 8 & 0 & 95 sequences to the Genus \\
\hline Elaphe escalaris 2 & 0 & 0 & 0 & 0 & $\begin{array}{l}94 \text { sequences to the Genus } \\
11 \text { microsatellites for } \\
\text { E. obsoleta }\end{array}$ \\
\hline Emys orbicularis & 127 & 93 & 34 & 0 & 130 sequences to the Genus \\
\hline $\begin{array}{l}\text { Iberolacerta cyrenil } \\
\text { Lacerta monticola }\end{array}$ & 45 & 40 & 5 & 0 & 218 sequences to the Genus \\
\hline Lacerta lepida & 69 & 66 & 3 & 0 & $\begin{array}{l}652 \text { sequences to the Genus } \\
9 \text { microsatellites for } L \text {. vivipara } \\
\text { and } 12 \text { for } L \text {. viridis }\end{array}$ \\
\hline Lacerta schreiberi & 36 & 32 & 4 & 0 & idem \\
\hline Macroprotodon cucullatus & 25 & 23 & 2 & 0 & 109 sequences to the Genus \\
\hline Mauremys leprosa & 9 & 9 & 0 & 0 & 149 sequences to the Genus \\
\hline Mauremys caspica & 14 & 11 & 3 & 0 & idem \\
\hline Malpolon monspessulanus & 13 & 10 & 3 & 0 & 16 sequences to the Genus \\
\hline Natrix maura & 21 & 20 & 1 & 0 & $\begin{array}{l}155 \text { sequences to the Genus } \\
8 \text { microsatellites for } N \text {. tesse- } \\
\text { llata }\end{array}$ \\
\hline Natrix natrix & 70 & 68 & 2 & 0 & idem \\
\hline Podarcis hispanica & 307 & yes & yes & 0 & $\begin{array}{l}954 \text { sequences to the Genus } \\
9 \text { microsatellites for } P . \text { bocagei, } \\
9 \text { for } P \text {. muralis and } \\
4 \text { for } P \text {. erhardii }\end{array}$ \\
\hline Podarcis muralis & 86 & 64 & 12 & 9 & idem \\
\hline Psammodromus algirus & 46 & 42 & 4 & 0 & 48 sequences to the Genus \\
\hline Psammodromus hispanicus & 2 & 2 & 0 & 0 & idem \\
\hline Tarentola mauritanica & 69 & 69 & 0 & 0 & 289 sequences to the Genus \\
\hline Vipera latastei & 2 & 2 & 0 & 0 & $\begin{array}{l}352 \text { sequences to the Genus } \\
6 \text { microsatellites for } V \text {. berus }\end{array}$ \\
\hline
\end{tabular}


groupped data for both entries (Squalius pyrenaicus/Leuciscus pyrenaicus). The data are current to November 16, 2005

\section{Results}

\section{FISHES}

Fishes species in Comunidad de Madrid are represented by a large number of molecular markers (Table 1). This result is logical if we consider that nine of twenty present species are exotic and with high economic value. Despite having a good number of sequences for Cobitis, no microsatellites has been described. Similarly, the absence of microsatellites for Gobio is remarkable. The taxonomic status of some species has been revised in recent years. In these cases, the search for the different synonymies shows a large number of molecular markers available. Additionally, a recent study (Larno et al., 2005) characterizes new microsatellite markers for Leuciscus that are probably useful in other species (Barinova et al., 2004).

\section{AMPHIBIA}

The 19 species present in Madrid are well represented in the GenBank (Table 2) except for Triturus boscai, Triturus pygmaeus and Triturus marmoratus, represented by 6,1 and 4 sequences respectively and Hyla meridionalis, represented by 11 sequences. However, the Genus Triturus and Hyla are represented by a high number of sequences and among them they are numerous microsatellites that could be useful. All of the genera are well represented, with microsatellites described for Alytes, Bufo, Hyla, Rana, Salamandra and Triturus. In particular, microsatellites are described for Alytes cisternasii, Bufo bufo, Bufo calamita, Hyla arborea, Salamandra salamandra and Triturus alpestris.

Sequences are available from specimens sampled within the Comunidad de Madrid for Alytes cisternasii, Alytes obstetricans, Discoglossus jeanneae and Salamandra salamandra which may help in population studies.

\section{REPTILIA}

Most species present in Comunidad de Madrid are well represented by sequences in databases (Table 3), except Chalcides bedriagai and Elaphe escalaris, and less so, Blanus cinereus, Coluber hippocrepis, Psammodromus hispanicus and Vipera latastei. However, they are many available sequences for the corresponding Genus except for Blanus.

With respect to microsatellites, a short number has been described for these species and genera. Only for Coronella austriaca and Podarcis muralis do we have microsatellites in GenBank, and at Genus level, microsatellites has been characterized for Elaphe, Lacerta, Natrix, Podarcis and Vipera. I believe that a supplementary effort in order to determine microsatellites for the Reptilia inhabiting the Comunidad de Madrid is necessary.

\section{Aves}

They are a large number of molecular markers for Aves, both sedentary (Table 4) and migrants (Table 5), that allow population, biogeographic and kinship studies. However, the number of markers is small for some genera. For this reason, it is necessary to implement the characterization of a larger number of molecular markers. For instance, there are no DNA markers for Melanocorypha among the sedentary group and other genera show a small number of markers (less than 10), including:

$\begin{array}{lll} & \text { Sedentary: } & \\ \text { Aegypius } & \text { Lullula } & \text { Pyrrhocorax } \\ \text { Amandava } & \text { Miliaria } & \text { Remiz } \\ \text { Bubulcus } & \text { Oenanthe } & \text { Saxicola } \\ \text { Egretta } & \text { Petronia } & \text { Tachybaptus } \\ \text { Elanus } & \text { Phoenicurus } & \text { Tetrax } \\ \text { Garrulus } & \text { Ptyonoprogne } & \text { Upupa } \\ & & \\ & \text { Migrants: } & \\ \text { Calandrella } & \text { Jinx } & \text { Pluvialis } \\ \text { Delichon } & \text { Lymnocryptes } & \text { Recurvirostra } \\ \text { Gelochelidon } & \text { Oenanthe } & \text { Saxicola } \\ \text { Himantopus } & \text { Philomachus } & \text { Scolopax } \\ \text { Ixobrychus } & \text { Phoenicurus } & \text { Tichodroma } \\ & & \end{array}$

On the other hand, there are microsatellites available for the following genera: Accipiter, Aegithalos, Alectoris, Anas, Aquila, Athene, Bubo, Buteo, Callipepla, Cettia, Columba, Corvus, Dendrocopos, Emberiza, Falco, Fringilla, Gyps, Hieraaetus, Larus, Loxia, Luscinia, Otis, Parus, Passer Phasianus, Phylloscopus, Pica, Podiceps, Prunella, Ptynoprogne, Saxicola and Strix within the sedentary group, and for genera: Acrocephalus, Anas, 
Table 4.- Sequences in database for sedentary Aves present in Comunidad de Madrid.

Tabla 4.- Secuencias en bases de datos para aves sedentarias presentes en la Comunidad de Madrid.

\begin{tabular}{|c|c|c|c|c|c|}
\hline$\overline{\text { Species }}$ & Sequences & $\begin{array}{l}\text { Mitochondrial } \\
\text { sequences }\end{array}$ & $\begin{array}{c}\text { Nuclear } \\
\text { sequences }\end{array}$ & Microsatellites & Remarks \\
\hline Accipiter gentilis & 50 & 13 & 13 & 24 & 113 sequences to the Genus \\
\hline Accipiter nisus & 12 & 3 & 9 & 0 & $\begin{array}{l}\text { idem. } 24 \text { microsatellites for } \\
\text { A. gentilis }\end{array}$ \\
\hline Actitis hypoleucos & 10 & 7 & 3 & 0 & 24 sequences to the genus \\
\hline Aegithalos caudatus & 16 & 10 & 5 & 1 & 21 sequences to the Genus \\
\hline Aegypius monachus & 5 & 4 & 1 & 0 & \\
\hline Alauda arvensis & 12 & 6 & 6 & 0 & \\
\hline Alcedo atthis & 8 & 3 & 5 & 0 & 14 sequences to the Genus \\
\hline Alectoris rufa & 91 & 32 & 36 & 23 & 316 sequences to the Genus \\
\hline Amandava amandava & 2 & 2 & 0 & 0 & 7 sequences to the Genus \\
\hline Anas clypeata & 11 & 6 & 5 & 0 & $\begin{array}{l}1879 \text { sequences to the Genus. } \\
\text { Microsatellites for } A \text {. platyrynchos }\end{array}$ \\
\hline Anas platyrynchos & 1111 & yes & yes & More than 300 & idem \\
\hline Anas strepera & 66 & 28 & 38 & 0 & idem \\
\hline Anthus spinoletta & 3 & 1 & 2 & 0 & 32 sequences to the Genus \\
\hline Aquila adalberti & 22 & 4 & 0 & 18 & $\begin{array}{l}208 \text { sequences to the Genus } \\
8 \text { microsatellites for } A \text {. heliaca }\end{array}$ \\
\hline Aquila chrysaetos & 30 & 18 & 12 & 0 & idem \\
\hline Asio otus & 22 & 17 & 5 & 0 & 37 sequences to the Genus \\
\hline Athene noctua & 9 & 9 & 0 & 0 & $\begin{array}{l}17 \text { sequences to the Genus. } \\
7 \text { microsatellites for } A \text {. cunicularia }\end{array}$ \\
\hline Aythya ferina & 1 & 1 & 0 & 0 & 18 sequences to the Genus \\
\hline Bubo bubo & 48 & 28 & 13 & 7 & 95 sequences to the genus \\
\hline Bubulcus ibis & 4 & 3 & 1 & 0 & \\
\hline Burhinus oedicnemus & 1 & 1 & 0 & 0 & 12 sequences to the Genus \\
\hline Buteo buteo & 123 & 65 & 2 & 56 & $\begin{array}{l}\text { Genome mitochondrial completed. } \\
265 \text { sequences to the Genus }\end{array}$ \\
\hline Callipepla californica & 19 & 11 & 1 & 7 & 35 sequences to the Genus. Exotic \\
\hline Carduelis cannabina & 1 & 1 & 0 & 0 & 78 sequences to the Genus \\
\hline Carduelis carduelis & 6 & 5 & 1 & 0 & idem \\
\hline Carduelis chloris & 19 & 15 & 4 & 0 & idem \\
\hline Certhia brachydactyla & 1 & 1 & 0 & 0 & 15 sequences to the Genus \\
\hline Cettia cetti & 6 & 6 & 0 & 0 & $\begin{array}{l}31 \text { sequences to the Genus. } \\
12 \text { microsatellites for } C \text {. diphone }\end{array}$ \\
\hline Cinclus cinclus & 37 & 31 & 6 & 0 & 42 sequences to the Genus \\
\hline Circus aeruginosus & 9 & 5 & 4 & 0 & 20 sequences to the genus \\
\hline Circus cyaneus & 4 & 4 & 0 & 0 & idem \\
\hline Cisticola jundicis & 2 & 2 & 0 & 0 & 11 sequences to the Genus \\
\hline Coccothraustes coccothraustes & 6 & 3 & 3 & 0 & 10sequenceas to the Genus \\
\hline Columba livia & 318 & yes & yes & 18 & 459 sequences to the Genus \\
\hline Columba oenas & 1 & 1 & 0 & 0 & idem. Microsatellites for C. livia \\
\hline Columba palumbus & 29 & 19 & 10 & 0 & idem \\
\hline Corvus corax & 282 & yes & yes & 1 & 439 sequences to the Genus \\
\hline Corvus corone & 17 & 8 & 9 & 0 & idem. 1 microsatellite for $C$. corax \\
\hline Corvus monedula & 6 & 1 & 5 & 0 & idem \\
\hline Cyanopica cooki & 8 & 8 & 0 & 0 & 73 sequences to the Genus \\
\hline Cyanopica cyanus & 65 & 62 & 3 & 0 & idem \\
\hline Dendrocopos major & 276 & yes & yes & 0 & $\begin{array}{l}296 \text { sequences to the Genus. } 3 \\
\text { microsatellites for } D \text {. leucopterus } \\
\text { and } 6 \text { for } D \text {. leucotos }\end{array}$ \\
\hline Dendrocopos minor & 0 & 0 & 0 & 0 & idem \\
\hline Egretta garzetta & 2 & 1 & 1 & 0 & 8 sequences to the Genus \\
\hline Elanus caeruleus & 0 & 0 & 0 & 0 & 3 sequences to the Genus \\
\hline Emberiza cioides & 4 & 4 & 0 & 0 & $\begin{array}{l}117 \text { sequences to the Genus. } 26 \\
\text { microsatellites for } E \text {. citrinella and } \\
7 \text { for } E \text {. schoeniclus }\end{array}$ \\
\hline
\end{tabular}


Table 4.-Cont.

\begin{tabular}{|c|c|c|c|c|c|}
\hline Species & Sequences & $\begin{array}{l}\text { Mitochondrial } \\
\text { sequences }\end{array}$ & $\begin{array}{c}\text { Nuclear } \\
\text { sequences }\end{array}$ & Microsatellites & Remarks \\
\hline Emberiza cirlus & 2 & 2 & 0 & 0 & idem \\
\hline Erithacus rubecula & 79 & 68 & 11 & 0 & \\
\hline Falco peregrinus & 180 & 108 & 43 & 29 & $\begin{array}{l}\text { Genome mitochondrial Completed. } \\
328 \text { sequences to the Genus. } \\
28 \text { microsatellites for } F \text {. peregrinus, } \\
8 \text { for } F \text {. rusticulos and } \\
2 \text { for } F \text {. punctatus }\end{array}$ \\
\hline Falco tinпипсиlus & 24 & 13 & 11 & 0 & idem \\
\hline Fringilla coelebs & 87 & 70 & 16 & 1 & $\begin{array}{l}121 \text { sequences to the Genus } \\
1 \text { satellite }\end{array}$ \\
\hline Fulica atra & 3 & 2 & 1 & 0 & 11 sequences to the Genus \\
\hline Galerida cristata & 13 & 11 & 2 & 0 & 24 sequences to the Genus \\
\hline Galerida theklae & 9 & 7 & 2 & 0 & idem \\
\hline Gallinula chloropus & 13 & 2 & 11 & 0 & \\
\hline Garrulus glandarius & 1 & 1 & 0 & 0 & 4 sequences to the Genus \\
\hline Gyps fulvus & 19 & 7 & 2 & 10 & 39 sequences to the Genus \\
\hline Hieraaetus fasciatus & 52 & 12 & 5 & 35 & 91 sequences to the Genus \\
\hline Lanius excubitor & 16 & 13 & 3 & 0 & 132 sequences to the Genus \\
\hline Lanius meridionalis & 38 & 35 & 3 & 0 & idem \\
\hline Larus ridibundus & 22 & 9 & 13 & 0 & $\begin{array}{l}710 \text { sequences to the genus. } 7 \text { micro- } \\
\text { satellites for } L \text {. novaehollandiae }\end{array}$ \\
\hline Loxia curvirostra & 43 & 39 & 4 & 0 & $\begin{array}{l}58 \text { sequences to the Genus. } 7 \text { micro- } \\
\text { satellites for } L \text {. scotica }\end{array}$ \\
\hline Lullula arborea & 2 & 2 & 0 & 0 & \\
\hline Luscinia svecica & 302 & yes & yes & 2 & 310 sequences to the genus \\
\hline Melanocorypha calandra & 0 & 0 & 0 & 0 & \\
\hline Miliaria calandra & 8 & 8 & 0 & 0 & \\
\hline Milvus milvus & 46 & 46 & 0 & 0 & 137 sequences to the genus \\
\hline Monticola solitarius & 4 & 3 & 1 & 0 & 21 sequences to the genus \\
\hline Motacilla alba & 494 & yes & yes & 0 & 1629 sequences to the Genus \\
\hline Motacilla cinerea & 27 & 23 & 4 & 0 & idem \\
\hline Myiopsitta monachus & 11 & 10 & 1 & 0 & Exotic \\
\hline Oenanthe leucura & 0 & 0 & 0 & 0 & 2 sequences to the Genus \\
\hline Otis tarda & 220 & yes & yes & 8 & \\
\hline Parus ater & 7 & 5 & 2 & 0 & $\begin{array}{l}1283 \text { sequences to the Genus. Micro- } \\
\text { satellites for } P \text {. major (23), P. mon- } \\
\text { ticolus (12) and } P \text {. caeruleus (12) }\end{array}$ \\
\hline Parus caeruleus & 268 & yes & yes & 12 & idem \\
\hline Parus cristatus & 1 & 1 & 0 & 0 & idem \\
\hline Parus major & 405 & yes & yes & 23 & idem \\
\hline Passer domesticus & 76 & 20 & 46 & 10 & 129 sequences to the Genus \\
\hline Passer hispaniolensis & 4 & 4 & 0 & 0 & $\begin{array}{l}\text { idem. Microsatellites for } P \text {. domes- } \\
\text { ticus }\end{array}$ \\
\hline Passer montanus & 29 & 18 & 11 & 0 & idem \\
\hline Petronia petronia & 5 & 2 & 3 & 0 & 8 sequences to the Genus \\
\hline Phasianus colchicus & 67 & 13 & 53 & 1 & 78 sequences to the Genus. Exotic \\
\hline Phoenicurus ochrurus & 0 & 0 & 0 & 0 & 5 sequences to the Genus \\
\hline Phylloscopus collybita & 18 & 14 & 4 & 0 & $\begin{array}{l}365 \text { sequences to the Genus. } 8 \text { micro- } \\
\text { satellites for } P \text {. occipitalis, } 2 \text { for } P \text {. } \\
\text { trochilus and } 10 \text { for } P \text {. iijimae }\end{array}$ \\
\hline Phylloscopus ibericus & 0 & 0 & 0 & 0 & idem \\
\hline Pica pica & 50 & 39 & 7 & 4 & 60 sequences to the Genus \\
\hline Picus viridis & 3 & 2 & 1 & 0 & 14 sequences to the Genus \\
\hline Porphyrio porphyrio & 2 & 0 & 2 & 0 & 15 sequences to the Genus \\
\hline Podiceps cristatus & 2 & 0 & 2 & 0 & $\begin{array}{l}36 \text { sequences to the Genus. } 7 \text { micro- } \\
\text { satellites for } P \text {. grisegena }\end{array}$ \\
\hline Podiceps nigricollis & 1 & 1 & 0 & 0 & idem \\
\hline Prunella collaris & 16 & 0 & 7 & 9 & 38 sequences to the Genus \\
\hline Prunella modularis & 11 & 4 & 7 & 0 & idem. 9 microsatellites for $P$. collaris \\
\hline Pterocles alchata & 0 & 0 & 0 & 0 & 98 sequences to the Genus \\
\hline
\end{tabular}


Table 4.-End.

\begin{tabular}{|c|c|c|c|c|c|}
\hline Species & Sequences & $\begin{array}{l}\text { Mitochondrial } \\
\text { sequences }\end{array}$ & $\begin{array}{c}\text { Nuclear } \\
\text { sequences }\end{array}$ & Microsatellites & Remarks \\
\hline Pterocles orientalis & 1 & 0 & 1 & 0 & idem \\
\hline Ptyonoprogne rupestris & 2 & 2 & 0 & 0 & $\begin{array}{l}5 \text { sequences to the Genus. } 1 \text { micro- } \\
\text { satellite for } P \text {. fuligula }\end{array}$ \\
\hline Pyrrhocorax pyrrhocorax & 4 & 2 & 2 & 0 & 6 sequences to the Genus \\
\hline Rallus aquaticus & 3 & 3 & 0 & 0 & 12 sequences to the Genus \\
\hline Regulus ignicapillus & 4 & 4 & 0 & 0 & 54 sequences to the Genus \\
\hline Regulus regulus & 24 & 24 & 0 & 0 & idem \\
\hline Remiz pendulinus & 7 & 2 & 5 & 0 & \\
\hline Saxicola torquata & 2 & 2 & 0 & 0 & $\begin{array}{l}8 \text { sequences to the Genus. } 1 \text { micro- } \\
\text { satellite for } S \text {. rubertra }\end{array}$ \\
\hline Serinus citrinella & 1 & 1 & 0 & 0 & 73 sequences to the Genus \\
\hline Serinus serinus & 5 & 5 & 0 & 0 & idem \\
\hline Sitta europaea & 287 & yes & yes & 0 & 392 sequences to the Genus \\
\hline Strix aluco & 328 & yes & yes & 0 & $\begin{array}{l}417 \text { sequences to the Genus. } 7 \text { micro- } \\
\text { satellites for } S \text {. occidentalis }\end{array}$ \\
\hline Sturnus unicolor & 0 & 0 & 0 & 0 & 32 sequences to the Genus \\
\hline Sylvia melanocephala & 5 & 5 & 0 & 0 & 54 sequences to the Genus \\
\hline Sylvia undata & 1 & 1 & 0 & 0 & idem \\
\hline Tachybapthus ruficollis & 1 & 1 & 0 & 0 & \\
\hline Tetrax tetrax & 6 & 4 & 2 & 0 & \\
\hline Troglodytes troglodytes & 149 & 146 & 3 & 0 & 190 sequences to the Genus \\
\hline Turdus merula & 8 & 3 & 5 & 0 & 197 sequences to the Genus \\
\hline Turdus philomelos & 6 & 4 & 2 & 0 & idem \\
\hline Turdus viscivorus & 1 & 0 & 1 & 0 & idem \\
\hline Tyto alba & 34 & 24 & 10 & 0 & 59 sequences to the Genus \\
\hline Upupa epops & 7 & 4 & 3 & 0 & \\
\hline Vanellus vanellus & 3 & 2 & 1 & 0 & 11 sequences to the Genus \\
\hline
\end{tabular}

Anser, Ardea, Calidris, Charadrius, Clamator, Corvus, Coturnix, Cuculus, Emberiza, Falco, Ficedula, Gallinago, Grus, Hirundo, Larus, Locustella Luscinia, Merops, Muscicapa, Otus, Phalacrocorax, Phylloscopus, Philomachus Phyrrula, Riparia, Saxicola and Sterna among the migratory group.

It is necessary to remark the absence of microsatellites for Turdus and Ciconia, and the presence of only one microsatellite sequence for Corvus. The case of Philomachus is also interesting. In this genus, the nine sequences available are microsatellites.

\section{MAMMALS}

Mammals are well represented by sequences in databases except for the endangered species Galemys pyrenaicus with only four sequences deposited in GenBank.

In respect to the microsatellites, the number of sequences is large, except for Barbastella, Elyomis,
Genetta, Hypsugo, Neomys, Pipistrellus, Suncus and Talpa, with no microsatellites characterized.

\section{Conclusions}

The species and genera without molecular data deserve a particular effort for the characterization of molecular markers. In particular, I think that is necessary to invest in the obtention of more sequences from the endangered Galemys pyrenaicus, and to obtain sequences for underrepresented avian genera, such as Elanus, Aegypius, Melanocorypha, Lymnocryptes and others.

On the other hand, it is also necessary to characterize microsatellites for genera with no sequences available, considering the current importance of these markers (Bruford \& Wayne, 1993), and in particular, a major effort in the characterization of microsatellites in reptiles and fish should be undertaken. 
Table 5.- Sequences in databases for migrant Aves present in Comunidad de Madrid.

Tabla 5.- Secuencias en bases de datos para aves migrantes presentes en la Comunidad de Madrid.

\begin{tabular}{|c|c|c|c|c|c|}
\hline Species & Sequences & $\begin{array}{l}\text { Mitochondrial } \\
\text { sequences }\end{array}$ & $\begin{array}{l}\text { Nuclear } \\
\text { sequences }\end{array}$ & Microsatellites & Remarks \\
\hline Acrocephalus arundinaceus & 71 & 6 & 53 & 12 & $\begin{array}{l}294 \text { sequences to the Genus. } 67 \\
\text { microsatellites for } A \text {. sechellensis, } \\
3 \text { for } A \text {. paludicola and } 1 \text { for } A \text {. } \\
\text { orientalis }\end{array}$ \\
\hline Acrocephalus schoenubaenus & 10 & 10 & 0 & 0 & idem \\
\hline Acrocephalus scirpaceus & 12 & 12 & 0 & 0 & idem \\
\hline Anas acuta & 11 & 8 & 3 & 0 & $\begin{array}{l}1879 \text { sequences to the genus. } \\
\text { Microsatellites for } \text { A. platyrynchos }\end{array}$ \\
\hline Anas crecca & 9 & 5 & 4 & 0 & idem \\
\hline Anas penelope & 63 & 23 & 40 & 0 & idem \\
\hline Anas querquedula & 5 & 5 & 0 & 0 & idem \\
\hline Anser anser & 82 & 12 & 70 & 0 & $\begin{array}{l}325 \text { sequences to the Genus. } 47 \\
\text { microsatellites para } A \text {. cygnoides } \\
\text { and } 2 \text { for } A \text {. albifrons }\end{array}$ \\
\hline Anthus campestris & 1 & 1 & 0 & 0 & 32 sequences to the Genus \\
\hline Anthus pratensis & 9 & 6 & 3 & 0 & idem \\
\hline Anthus trivialis & 5 & 2 & 3 & 0 & idem \\
\hline Apus apus & 17 & 14 & 3 & 0 & 37 sequences to the Genus \\
\hline Apus pallidus & 0 & 0 & 0 & 0 & idem \\
\hline Ardea cinerea & 5 & 2 & 3 & 0 & $\begin{array}{l}76 \text { sequences to the Genus. } 60 \\
\text { microsatélites for } A \text {. herodias }\end{array}$ \\
\hline Ardea purpurea & 1 & 1 & 0 & 0 & idem \\
\hline Asio flammeus & 15 & 12 & 3 & 0 & 37 sequences to the Genus \\
\hline Aythya fuligula & 2 & 1 & 1 & 0 & 18 sequences to the Genus \\
\hline Aythya nycora & 1 & 1 & 0 & 0 & idem \\
\hline Calandrella brachydactyla & 0 & 0 & 0 & 0 & 4 sequences to the Genus \\
\hline Calidris alpina & 43 & 41 & 2 & 0 & $\begin{array}{l}341 \text { sequences to the Genus. } 3 \\
\text { microsatellites for } C \text {. canutus }\end{array}$ \\
\hline Calidris ferruginea & 2 & 2 & 0 & 0 & idem \\
\hline Calidris minuta & 0 & 0 & 0 & 0 & idem \\
\hline Caprimulgus europeus & 3 & 2 & 1 & 0 & 15 sequences to the Genus \\
\hline Caprimulgus ruficollis & 0 & 0 & 0 & 0 & idem \\
\hline Carduelis spinus & 3 & 3 & 0 & 0 & 78 sequences to the Genus \\
\hline Charadrius dubius & 1 & 0 & 1 & 0 & $\begin{array}{l}183 \text { sequences to the Genus. } 66 \\
\text { microsatellites for } C \text {. alexandrinus }\end{array}$ \\
\hline Charadrius hiatiluca & 0 & 0 & 0 & 0 & idem \\
\hline Chlidonias hybridus & 3 & 3 & 0 & 0 & 10 sequence to the Genus \\
\hline Chlidonias niger & 4 & 4 & 0 & 0 & idem \\
\hline Ciconia ciconia & 7 & 5 & 2 & 0 & $\begin{array}{l}\text { Genome mitochondrial completed. } \\
74 \text { sequences to the Genus }\end{array}$ \\
\hline Ciconia nigra & 15 & 10 & 5 & 0 & idem \\
\hline Circaetus gallicus & 8 & 5 & 3 & 0 & 19 sequences to the Genus \\
\hline Circus pygargus & 0 & 0 & 0 & 0 & 20 sequences to the genus \\
\hline Clamator glandarius & 10 & 3 & 0 & 7 & 13 sequences to the Genus \\
\hline Coracias garrulus & 5 & 4 & 1 & 0 & 24 sequences to the Genus \\
\hline Corvus frugileus & 7 & 4 & 3 & 0 & $\begin{array}{l}439 \text { sequences to the Genus. } 1 \\
\text { micosatellite for } C \text {. corax. } \\
\text { Genome mitochondrial completed }\end{array}$ \\
\hline Coturnix coturnix & 294 & yes & yes & 0 & $\begin{array}{l}648 \text { sequences to the genus. } 115 \\
\text { microsatellites for } C \text {. japonica }\end{array}$ \\
\hline Cuculus canorus & 45 & 32 & 6 & 7 & 63 sequences to the Genus \\
\hline Delichon urbica & 3 & 2 & 1 & 0 & 8 sequences to the Genus \\
\hline Emberiza citrinella & 39 & 6 & 7 & 26 & $\begin{array}{l}117 \text { sequences to the Genus. } 26 \\
\text { microsatellites for } E \text {. citrinella and } \\
7 \text { for } E \text {. schoeniclus }\end{array}$ \\
\hline Emberiza hortelana & 0 & 0 & 0 & 0 & idem \\
\hline Emberiza schoeniclus & 37 & 23 & 7 & 7 & idem \\
\hline Falco columbarius & 14 & 4 & 10 & 0 & $\begin{array}{l}328 \text { sequences to the Genus. } 28 \text { micro- } \\
\text { satellites for } F \text {. peregrinus, } 8 \text { for } F \text {. } \\
\text { rusticulos and } 2 \text { for } F \text {. punctatus }\end{array}$ \\
\hline
\end{tabular}


Table 5. Cont.

\begin{tabular}{|c|c|c|c|c|c|}
\hline Species & Sequences & $\begin{array}{l}\text { Mitochondrial } \\
\text { sequences }\end{array}$ & $\begin{array}{c}\text { Nuclear } \\
\text { sequences }\end{array}$ & Microsatellites & Remarks \\
\hline Falco eleanorae & 0 & 0 & 0 & 0 & idem \\
\hline Falco naumanni & 1 & 1 & 0 & 0 & idem \\
\hline Falco subbuteo & 3 & 3 & 0 & 0 & idem \\
\hline Ficedula hypoleuca & 164 & 60 & 81 & 23 & $\begin{array}{l}350 \text { sequences to the genus. Other } \\
\text { microsatellites }\end{array}$ \\
\hline Fringilla montifrigilla & 23 & 16 & 7 & 0 & 121 sequences to the Genus \\
\hline Gallinago gallinago & 7 & 3 & 4 & 0 & $\begin{array}{l}118 \text { sequences to the Genus. } \\
\text { Microsatellites for } G \text {. media }\end{array}$ \\
\hline Gelochelidon nilotica & 1 & 1 & 0 & 0 & \\
\hline Grus grus & 11 & 6 & 5 & 0 & $\begin{array}{l}349 \text { sequences to the Genus. } 35 \\
\text { microsatellites for } G \text {. americana, } \\
7 \text { for } G \text {. japonensis, } 1 \text { for } G \text {. para- } \\
\text { disea and } 1 \text { for } G \text {. canadiensis }\end{array}$ \\
\hline Hieraaetus pennatus & 11 & 7 & 4 & 0 & 91 sequences to the Genus \\
\hline Himantopus himantopus & 1 & 0 & 1 & 0 & 4 sequences to the Genus. \\
\hline Hippolais polyglotta & 4 & 4 & 0 & 0 & 27 sequences to the Genus \\
\hline Hirundo daurica & 0 & 0 & 0 & 0 & $\begin{array}{l}89 \text { sequences to the Genus. } \\
\text { Microsatellites for } H \text {. rustica }\end{array}$ \\
\hline Hirundo rustica & 45 & 14 & 15 & 16 & idem \\
\hline Ixobrychus minutus & 0 & 0 & 0 & 0 & 5 sequences to the Genus \\
\hline Jynx torquilla & 4 & 3 & 1 & 0 & \\
\hline Lanius collurio & 9 & 4 & 5 & 0 & 132 sequences to the Genus \\
\hline Lanius senator & 6 & 6 & 0 & 0 & idem \\
\hline Larus cachinnans & 57 & 57 & 0 & 0 & $\begin{array}{l}710 \text { sequences to the Genus. } 7 \text { micro- } \\
\text { satellites for } L . \text { novaehollandiae }\end{array}$ \\
\hline Larus fuscus & 72 & 62 & 10 & 0 & idem \\
\hline Larus melanocephalus & 4 & 4 & 0 & 0 & idem \\
\hline Limosa limosa & 4 & 4 & 0 & 0 & 27 sequences to the Genus \\
\hline Locustella luscinoides & 3 & 3 & 0 & 0 & $\begin{array}{l}63 \text { sequences to the Genus. } \\
7 \text { microsatellites for } L \text {. pyeri }\end{array}$ \\
\hline Locustella naevia & 7 & 7 & 0 & 0 & idem \\
\hline Luscinia megarhynchos & 0 & 0 & 0 & 0 & $\begin{array}{l}310 \text { sequences to the Genus. } \\
2 \text { microsatellites for } L \text {. svecica }\end{array}$ \\
\hline Lymnocryptes minimus & 1 & 1 & 0 & 0 & \\
\hline Merops apiaster & 20 & 0 & 0 & 20 & 30 sequences to the Genus \\
\hline Milvus migrans & 91 & 87 & 4 & 0 & 137 sequences to the Genus \\
\hline Monticola saxatalis & 0 & 0 & 0 & 0 & 21 sequences to the Genus \\
\hline Motacilla flava & 885 & yes & yes & 0 & 1629 sequences to the Genus \\
\hline Muscicapa striata & 23 & 5 & 15 & 3 & 37 sequences to the Genus \\
\hline Neophron percnopterus & 33 & 31 & 2 & 0 & \\
\hline Numenius arquata & 2 & 2 & 0 & 0 & 13 sequences to the Genus \\
\hline Nycticorax nycticorax & 13 & 8 & 5 & 0 & \\
\hline Oenanthe hispanica & 0 & 0 & 0 & 0 & 2 sequences to the Genus \\
\hline Oenanthe oenanthe & 1 & 1 & 0 & 0 & idem \\
\hline Oriolus oriolus & 3 & 0 & 3 & 0 & 15 sequences to the Genus \\
\hline Otus scops & 10 & 6 & 4 & 0 & $\begin{array}{l}118 \text { sequences to the Genus. } 18 \\
\text { microsatellites for } O \text {. elegans }\end{array}$ \\
\hline Pandion haliaetus & 16 & 8 & 8 & 0 & \\
\hline Pernis apivorus & 7 & 7 & 0 & 0 & 38 sequences to the Genus \\
\hline Phalacrocorax carbo & 38 & 27 & 4 & 7 & 112 sequences to the Genus \\
\hline Philomachus pugnax & 9 & 0 & 0 & 9 & \\
\hline Phoenicurus phoenicurus & 2 & 2 & 0 & 0 & 5 sequences to the Genus \\
\hline Phylloscopus bonelli & 5 & 5 & 0 & 0 & $\begin{array}{l}365 \text { sequences to the genus. } 8 \\
\text { microsatellites for } P \text {. occipitalis, } 2 \\
\text { for } P \text {. trochilus and } 10 \text { for } P \text {. iijimae }\end{array}$ \\
\hline Phylloscopus trochilus & 28 & 10 & 16 & 2 & idem \\
\hline Platalea leucorodia & 0 & 0 & 0 & 0 & 267 sequences to the Genus \\
\hline Pluvialis apricaria & 0 & 0 & 0 & 0 & 7 sequences to the Genus \\
\hline Pyrrhula pyrrhula & 10 & 8 & 0 & 2 & 14 sequences to the Genus \\
\hline Recurvirostra avosetta & 4 & 2 & 2 & 0 & 8 sequences to the Genus \\
\hline Riparia riparia & 3 & 2 & 1 & 0 & $\begin{array}{l}11 \text { sequences to the Genus. } \\
1 \text { microsatellite for } R \text {.cincta }\end{array}$ \\
\hline Saxicola rubertra & 1 & 0 & 0 & 1 & 8 sequences to the Genus \\
\hline
\end{tabular}


Table 5. End.

\begin{tabular}{|c|c|c|c|c|c|}
\hline Species & Sequences & $\begin{array}{l}\text { Mitochondrial } \\
\text { sequences }\end{array}$ & $\begin{array}{c}\text { Nuclear } \\
\text { sequences }\end{array}$ & Microsatellites & Remarks \\
\hline Scolopax rusticola & 2 & 2 & 0 & 0 & 9 sequences to the Genus \\
\hline Sterna hirundo & 10 & 6 & 4 & 0 & $\begin{array}{l}120 \text { sequences to the Genus. } \\
4 \text { microsatellites for } S \text {. dougallii }\end{array}$ \\
\hline Streptopelia decaocto & 7 & 6 & 1 & 0 & 94 sequences to the Genus \\
\hline Streptopelia turtur & 7 & 6 & 1 & 0 & idem \\
\hline Sturnus vulgaris & 28 & 14 & 14 & 0 & 32 sequences to the Genus \\
\hline Sylvia atricapilla & 12 & 6 & 6 & 0 & 54 sequences to the Genus \\
\hline Sylvia borin & 8 & 5 & 3 & 0 & idem \\
\hline Sylvia cantillans & 3 & 3 & 0 & 0 & idem \\
\hline Silvia communis & 1 & 1 & 0 & 0 & idem \\
\hline Sylvia conspicillata & 1 & 1 & 0 & 0 & idem \\
\hline Sylvia hortensis & 1 & 1 & 0 & 0 & idem \\
\hline $\begin{array}{l}\text { Tachymarptis melbal } \\
\text { Apus melba }\end{array}$ & 11 & 8 & 3 & 0 & See Apus \\
\hline Tadorna tadorna & 9 & 7 & 2 & 0 & 22 sequences to the Genus \\
\hline Tichodroma muraria & 1 & 0 & 1 & 0 & \\
\hline Tringa erythropus & 9 & 7 & 2 & 0 & 113 sequences to the Genus \\
\hline Tringa glareola & 11 & 9 & 2 & 0 & idem \\
\hline Tringa nebularia & 10 & 8 & 2 & 0 & idem \\
\hline Tringa ochropus & 11 & 8 & 3 & 0 & idem \\
\hline Tringa totanus & 20 & 16 & 4 & 0 & idem \\
\hline Turdus ialicus & 0 & 0 & 0 & 0 & 197 sequences to the Genus \\
\hline Turdus pilaris & 0 & 0 & 0 & 0 & idem \\
\hline Turdus torquatus & 0 & 0 & 0 & 0 & idem \\
\hline
\end{tabular}

\section{ACKNOWLEDGMENTS}

Thanks to L. M. Carrascal, I. Doadrio, M. García París and J. E. Gónzalez for their commentaries and suggest. This work is partially supported by Comunidad de Madrid grant GR/AMB/0750/2004.

\section{References}

Avise, J. C., 2004. Molecular Markers, Natural History and Evolution. Second Edition. Sinauer. Sunderland. $341 \mathrm{pp}$.

BARINOVA, A., YAdREnKINA, E., NAKAJIMA, M. \& TANIGUCHI, N., 2004. Identification and characterization of microsatellite molecular markers developed in Leuciscus idus and Siberian Roach Rutilus rutilus. Molecular Ecology Notes, 4: 86-88.

Bruford, M. W. \& WAYNe, R. K., 1993. Microsatellites and their application to population genetic studies. Current Opinion in genetics and Development, 3: 939-943.

De la Puente, J., Pérez-Tris, J. \& Bermejo, A., (eds.). 2003. Anuario Ornitológico de Madrid 2002. SEO Monticola. Madrid. 207 pp.

DoAdrio, I., (ed.). 2002. Atlas y Libro Rojo de los Peces Continentales de España. Ministerio de Medio Ambiente. Madrid. 233 pp.

Larno, V., Launey, S., Devaux, A. \& Laroche, J., 2005. Isolation and Characterization of microsatelli- te loci from chub Leuciscus cephalus (Pisces: Cyprinidae). Molecular Ecology Notes, 5: 752-754.

Martínez-Solano, I. y GonzÁlez Fernández, J. E., 2003. La Colección de Anfibios de Madrid del Museo Nacional de Ciencias Naturales y su utilidad en conservación. Graellsia, 59: 105-128.

Palomo, L. J. \& Gisbert, J., (eds.). 2002. Atlas de los Mamiferos terrestres de España. Ministerio de Medio Ambiente. Madrid. 563 pp.

Pleguezuelos, J. M., Márquez, R. \& Lizana, M., (eds.). 2002. Atlas y Libro Rojo de los Anfibios y Reptiles de España. Ministerio de Medio Ambiente. Madrid. 587 pp.

Tautz, D., Arctander, P., Munelli, A., Thomas, R. H. \& Vogler, A. P., 2004. A plea for DNA Taxonomy. Trends in Ecology and Evolution, 18: 70-74.

\section{Note in Proof:}

Since the submission of this work and the proof corrections, and with respect to Aves, 4 microsatellites have been described for the genus Porphyrio and 16 for the species Nycticorax nycticorax. Many mitochondrial sequences have been published for the genus Scolopax. In the Reptilia, more sequences have been described for the genus Blanus, and 6 microsatellites have been described for Mauremys. Finally, many microsatellites have been described in the mammalian genus Mustela. 
Table 6.- Sequences in database for mammals present in Comunidad de Madrid.

Tabla 6.- Secuencias en bases de datos para mamíferos presentes en la Comunidad de Madrid.

\begin{tabular}{|c|c|c|c|c|c|}
\hline Species & Sequences & $\begin{array}{l}\text { Mitochondrial } \\
\text { sequences }\end{array}$ & $\begin{array}{l}\text { Nuclear } \\
\text { sequences }\end{array}$ & Microsatellites & Remarks \\
\hline Apodemus sylvaticus & 372 & yes & yes & 21 & $\begin{array}{l}1190 \text { sequences to the Genus } \\
\text { Several microsatellites }\end{array}$ \\
\hline Arvicola sapidus & 1 & 0 & 1 & 0 & $\begin{array}{l}58 \text { sequences to the Genus. } \\
21 \text { microsatellites for } A \text {. terrestris }\end{array}$ \\
\hline Barbastella barbastellus & 36 & 36 & 0 & 0 & 40 sequences to the genus \\
\hline Capra pyrenaica & 38 & 31 & 7 & 0 & $\begin{array}{l}3740 \text { sequences to the Genus. } \\
55 \text { microsatellites for } C \text {. hircus }\end{array}$ \\
\hline Capreolus capreolus & 358 & yes & yes & 16 & 383 sequences to the genus \\
\hline Cervus dama & 30 & 6 & 16 & 8 & $\begin{array}{l}859 \text { sequences to the Genus. } \\
125 \text { microsatellites }\end{array}$ \\
\hline Cervus elaphus & 405 & yes & yes & 82 & idem \\
\hline Crocidura russula & 310 & yes & yes & 23 & $\begin{array}{l}595 \text { sequences to the Genus. } \\
8 \text { microsatellites for } C \text {. suaveolens. } \\
\text { Genome mitochondrial completed }\end{array}$ \\
\hline Eliomys quercinus & 7 & 2 & 5 & 0 & 11 sequences to the Genus \\
\hline Eptesicus serotinus & 18 & 9 & 9 & 0 & $\begin{array}{l}80 \text { sequences to the Genus. } \\
9 \text { microsatellites for } E \text {. fuscus }\end{array}$ \\
\hline Erinaceus europaeus & 185 & 96 & 77 & 12 & 303 sequences to the Genus. \\
\hline Felis silvestris & 54 & 28 & 26 & 0 & $\begin{array}{l}6313 \text { sequences to the genus. } \\
548 \text { microsatellites }\end{array}$ \\
\hline Galemys pyrenaicus & 4 & 1 & 3 & 0 & \\
\hline Genetta genetta & 27 & 22 & 5 & 0 & 125 sequences to the Genus \\
\hline Hypsugo savii & 18 & 18 & 0 & 0 & 20 sequences to the Genus \\
\hline Lepus granatensis & 104 & 51 & 53 & 0 & $\begin{array}{l}1168 \text { sequences to the Genus. } \\
8 \text { microsatellites for } L \text {. saxatilis } \\
\text { and } 6 \text { for L. europaeus }\end{array}$ \\
\hline Lutra lutra & 118 & 81 & 10 & 27 & 130 sequences to the genus \\
\hline Lynx pardinus & 29 & 26 & 3 & 0 & $\begin{array}{l}226 \text { sequences to the Genus } \\
6 \text { microsatellites for L. canadiensis } \\
\text { and } 35 \text { for L. rufus. }\end{array}$ \\
\hline Martes foina & 29 & 13 & 11 & 5 & $\begin{array}{l}442 \text { sequences to the Genus. } \\
27 \text { microsatellites }\end{array}$ \\
\hline Meles meles & 216 & yes & yes & 130 & \\
\hline Microtus cabrerae & 34 & 2 & 32 & 0 & $\begin{array}{l}1615 \text { sequences to the Genus. } \\
8 \text { microsatellites for } M \text {. oeconomus } \\
\text { and } 8 \text { for } M \text {. montebelli }\end{array}$ \\
\hline Microtus duodecimcostatus & 4 & 2 & 2 & 0 & idem \\
\hline $\begin{array}{l}\text { Microtus lusitanicus } \\
\text { Microtus nivalis/ }\end{array}$ & 6 & 2 & 4 & 0 & idem \\
\hline Chionomys nivalis & 21 & 11 & 10 & 0 & $\begin{array}{l}\text { Idem } \\
\text { ( } 7 \text { sequences to Chionomys) }\end{array}$ \\
\hline Miniopterus schreibersii & 123 & 110 & 8 & 5 & 171 sequences to the Genus \\
\hline Mus musculus & 8093572 & yes & yes & more than 600 & 8099741 sequences to the Genus. \\
\hline Mustela nivalis & 55 & 48 & 5 & 2 & $\begin{array}{l}585 \text { sequences to the genus. } \\
81 \text { microsatellites }\end{array}$ \\
\hline Mustela putorius & 102 & 36 & 65 & 1 & Idem \\
\hline Mustela vison & 206 & yes & yes & 63 & idem \\
\hline Myotis bechsteini & 10 & 10 & 0 & 0 & $\begin{array}{l}711 \text { sequences to the Genus. } \\
41 \text { microsatellites for } M \text {. myotis }\end{array}$ \\
\hline Myotis blythii & 14 & 14 & 0 & 0 & idem \\
\hline Myotis daubentoni & 42 & 17 & 25 & 0 & idem \\
\hline Myotis emarginatus & 6 & 6 & 0 & 0 & idem \\
\hline Myotis myotis & 168 & 30 & 97 & 41 & idem \\
\hline Myotis mystacinus & 33 & 33 & 0 & 0 & idem \\
\hline Myotis nattereri & 6 & 6 & 0 & 0 & idem \\
\hline Neomys anomalus & 10 & 9 & 1 & 0 & 26 sequences to the Genus \\
\hline Nyctalus lasiopterus & 6 & 6 & 0 & 0 & $\begin{array}{l}68 \text { sequences to the Genus. } \\
10 \text { microsatellites to } N \text {. noctula }\end{array}$ \\
\hline Nyctalus leisleri & 8 & 8 & 0 & 0 & idem \\
\hline Nyctalus noctula & 36 & 24 & 2 & 10 & idem \\
\hline
\end{tabular}


Table 6. End.

\begin{tabular}{|c|c|c|c|c|c|}
\hline Species & Sequences & $\begin{array}{l}\text { Mitochondrial } \\
\text { sequences }\end{array}$ & $\begin{array}{c}\text { Nuclear } \\
\text { sequences }\end{array}$ & Microsatellites & Remarks \\
\hline Oryctolagus cuniculus & 738692 & yes & yes & More than 400 & 738795 sequences to the genus \\
\hline Ovis gmelini & 0 & 0 & 0 & 0 & $\begin{array}{l}392342 \text { sequences to the Genus. } \\
\text { Many microsatellites }\end{array}$ \\
\hline Pipistrellus kuhli & 27 & 17 & 10 & 0 & 212 sequences to the Genus \\
\hline Pipistrellus nathusii & 13 & 13 & 0 & 0 & idem \\
\hline Pipistrellus pipistrellus & 78 & 72 & 6 & 0 & idem \\
\hline Plecotus auritus & 88 & 77 & 5 & 6 & 509 sequences to the Genus \\
\hline Plecotus austriacus & 54 & 54 & 0 & 0 & Idem. Microsatellites for $P$. auritus \\
\hline Rhinolophus euryale & 1 & 1 & 0 & 0 & $\begin{array}{l}1605 \text { sequences to the Genus. } \\
\text { Microsatellites for } R \text {. ferrumequinum } \\
\text { and } 14 \text { for } R \text {. hipposideros }\end{array}$ \\
\hline Rhinolophus ferrumequinum & 1453 & yes & yes & 33 & idem \\
\hline Rhinolophus hipposideros & 17 & 3 & 0 & 14 & idem \\
\hline Rhinolophus mehelyi & 0 & 0 & 0 & 0 & idem \\
\hline Sciurus vulgaris & 105 & 68 & 11 & 26 & 305 sequences to the Genus \\
\hline Sorex granarius & 2 & 2 & 0 & 0 & $\begin{array}{l}662684 \text { sequences to the Genus. } 3 \\
\text { microsatellites for } S \text {. cacutiens, } 3 \text { for } \\
\text { S. unguiculatus and } 20 \text { for } S \text {. araneus }\end{array}$ \\
\hline Sorex minutus & 75 & 75 & 0 & 0 & idem \\
\hline Suncus etruscus & 2 & 2 & 0 & 0 & 62 sequences to the Genus \\
\hline Sus scrofa & 1113105 & yes & yes & More than 2000 & 1113336 sequences to the Genus. \\
\hline Tadarida teniotis & 1 & 1 & 0 & 0 & $\begin{array}{l}269 \text { sequences to the Genus. } \\
9 \text { microsatellites for } T \text {. brasiliensis }\end{array}$ \\
\hline Talpa occidentalis & 2 & 1 & 1 & 0 & 45 sequences to the Genus \\
\hline Vulpes vulpes & 159 & 94 & 41 & 24 & 209 sequences to the Genus \\
\hline
\end{tabular}

